УДК 612.119+616.155.392-036.12+616.15-07

\author{
М. В. Дяченко ${ }^{1}$, І. З. Борбуляк ${ }^{1}$, Д. І. Білько ${ }^{1}$, Т. П. Перехрестенко ${ }^{3}$, \\ Н. М. Третяк ${ }^{3}$ I. С. Дягіль ${ }^{2}$, Н. М. Білько ${ }^{1}$ \\ ${ }^{1}$ Центр молекулярних і клітинних досліджень \\ Наиіонального університету «Києво-Могилянська академія» \\ ${ }^{2}$ Науковий иеентр радіаційної медиични НАМН Украйни \\ ${ }^{3}$ Інститут гематології та трансфузіологї̈ НАМН України
}

\title{
ЗВ'ЯЗОК ФУНКЦІОНАЛЬНОЇ АКТИВНОСТІ \\ КЛІТИН-ПОПЕРЕДНИКІВ КІСТКОВОГО МОЗКУ ПРИ ХРОНІЧНІЙ МІЄЛОЇДНІЙ ЛЕЙКЕМІЇ З ІНДИВІДУАЛЬНОЮ ВІДПОВІДДЮ НА ТЕРАПІЮ
}

\begin{abstract}
Показано ефективність застосування культуральних методів дослідження клітин-попередників кісткового мозку для моніторингу індивідуальної відповіді пацієнтів із хронічною мієлоїдною лейкемісю на терапію інгібіторами тирозинкіназ (ТКі). Аналіз особливостей росту гемопоетичних клітин при хронічній міслоїдній лейкемії показав, що функціональна активність кровотвірних клітин-попередників у осіб, які демонструють повну відповідь на терапію ТКі, була достовірно нижчою $(p<0,05)$ ефективності колонісутворення для зразків кісткового мозку осіб із відсутністю відповіді на терапію. Виявлено кореляцію між показниками колонісутворення та відсотком клітин із філадельфійською хромосомою у кістковому мозку, що була позитивною для групи осіб, які отримували альтернативне лікування гідроксисечовиною, та негативною для групи осіб із резистентністю до терапії ТКі.
\end{abstract}

$$
\begin{aligned}
& \text { М. В. Дяченко }{ }^{1} \text {, И. З. Борбуляк }{ }^{1} \text {, Д. И. Билько }{ }^{1} \text {, Т. П. Перехрестенко }{ }^{3} \text {, } \\
& \text { Н. Н. Третяк }{ }^{3} \text {, И. С. Дягиль }{ }^{2} \text {, Н. М. Билько }{ }^{1} \\
& { }^{1} \text { Центр молекулярных и клеточных исследований } \\
& \text { Национального университета «Киево-Могилянская академия» } \\
& { }^{2} \text { Научный иеентр радиачионной медицины НАМН Украины } \\
& { }^{3} \text { Институт гематологии и трансфузиологии НАМН Украины } \\
& \text { СВЯЗЬ ФУНКЦИОНАЛЬНОЙ АКТИВНОСТИ } \\
& \text { КЛЕТОК-ПРЕДШЕСТВЕННИКОВ КОСТНОГО МОЗГА } \\
& \text { ПРИ ХРОНИЧЕСКОЙ МИЕЛОИДНОЙ ЛЕЙКЕМИИ } \\
& \text { С ИНДИВИДУАЛЬНЫМ ОТВЕТОМ НА ТЕРАПИЮ }
\end{aligned}
$$

Показана эффективность применения культуральных методов исследования клетокпредшественников костного мозга для мониторинга индивидуального ответа пациентов с хронической миелоидной лейкемией на терапию ингибиторами тирозинкиназ (ТКи). Анализ особенностей роста гемопоэтических клеток при хронической миелоидной лейкемии показал, что функциональная активность кроветворных клеток-предшественников лиц, которые демонстрируют полный ответ на терапию ТКи, была достоверно ниже $(p<0,05)$ эффективности колониеобразования для образцов костного мозга у лиц с отсутствием ответа на терапию. Выявлена корреляция между показателями колониеобразования и процентом $\mathrm{Ph}^{+}$клеток в костном мозге, которая была позитивной для пациентов, получавших альтернативное лечение гидроксимочевиной, и отрицательной для группы лиц с резистентностью к терапии ТКи.

(C) М. В. Дяченко, І. З. Борбуляк, Д. І. Білько, Т. П. Перехрестенко, Н. М. Третяк, І. С. Дягіль, Н. М. Білько, 2012 
M. V. Diachenko ${ }^{1}$, I. Z. Borbulyak ${ }^{1}$, D. I. Bilko ${ }^{1}$, T. P. Perekhrestenko ${ }^{3}$, N. M. Tretyak ${ }^{3}$, I. S. Dyagil ${ }^{2}$, N. M. Bilko ${ }^{1}$

${ }^{1}$ Centre for Molecular and Cell Research of the National University of Kyiv-Mohyla Academy ${ }^{2}$ Scientific Centre of the Radiation Medicine NAMS of Ukraine

${ }^{3}$ Institute of Haemotology and Transfusiology NAMS of Ukraine

\title{
FUNCTIONAL ACTIVITY OF BONE MARROW PROGENITOR CELLS IN PATIENTS WITH CHRONIC MYELOID LEUKEMIA RELATED TO INDIVIDUAL RESPONSE TO THERAPY
}

\begin{abstract}
The paper presents an effective method of the monitoring of individual response of the patients with chronic myeloid leukemia (CML) to the therapy with tyrosine kinase inhibitors (TKi). The growth patterns analysis of hematopoietic cells from CML patients showed that functional activity of bone marrow progenitor cells of the patients with complete response to TKi therapy was significantly lower $(p<0.05)$ in comparison with the colony-forming efficiency of bone marrow sampled from patients with a resistance to the therapy. The correlations were revealed between numbers of colony-forming units and the percentage of $\mathrm{Ph}+$ cells in the bone marrow. This correlation was positive for the group of patients who were alternatively treated with the hydroxyurea and negative for the group of individuals with the resistance to TKi therapy.
\end{abstract}

\section{Вступ}

Хронічна мієлоїдна лейкемія (ХМЛ) - клональне порушення кровотворення, що виникає внаслідок появи генетичних аномалій на рівні гемопоетичної стовбурової клітини [5]. Це перше захворювання, для якого спочатку було продемонстровано майже стовідсоткову асоціацію з унікальною хромосомною аномалією - філадельфійською хромосомою $(\mathrm{Ph})$ - яка є наслідком реципрокної транслокації t(9;22)(q34;q11), а зрештою охарактеризовано молекулярний продукт зазначеної транслокації - химерний ген BCR-ABL.

При лікуванні даного захворювання інгібітор тирозинкінази Іматиніб мезилат (STI571, Glivec) використовується як сучасний високоефективний терапевтичний засіб [4]. Проте клінічні дослідження не підтвердили очікувані результати лікування із застосуванням Іматинібу через обмежену ефективність цього препарату щодо стовбурових клітин, що перебувають у стані спокою, а також індивідуальну варіабельність відповіді на терапію [3]. Визначення ступеня та швидкості відповіді на терапію Іматинібом вкрай необхідне і передусім потрібне для того, щоб якнайшвидше вирізнити групу пацієнтів із ХМЛ, котрі не відповідають на лікування у певні строки, і своєчасно прийняти рішення про корекцію дози або зміну лікувальної тактики взагалі [1].

Доведено, що рання відповідь на лікування Іматинібом корелює з кращими результатами виживання [2;6]. Тому вкрай актуальною залишається розробка методів моніторингу ефективності лікування задля його індивідуальної корекції для кожного окремого випадку захворювання.

Мета даної роботи - оцінити функціональні та цитоморфологічні особливості клітин-попередників на різних стадіях розвитку ХМЛ у культурі in vitro для раннього виявлення прогресії ХМЛ у фазу акселерації або бластний криз.

\section{Матеріал і методи досліджень}

Проаналізовано аспірати кісткового мозку 28 хворих на ХМЛ віком 20-46 років, які отримували лікування препаратом Іматиніб (Novartis) 5-36 місяців. Пацієнти були обстежені на етапі встановлення діагнозу гематологічними та молекулярно-цитогенетичними методами дослідження для підтвердження діагнозу. Паралельно із цим проводили культивування кровотвірних клітин-попередників кісткового мозку in vitro 
у напіврідкому агарі. Мононуклеари культивували у 24-лунковому планшеті при температурі $+37{ }^{\circ} \mathrm{C}$, за умов абсолютної вологості та $5 \% \mathrm{CO}_{2}$ із додаванням середовища DMEM, 20 \% фетальної телячої сироватки, 0,33 \% бакто-агару Difco, 50 нг/мл GMCSF та антибіотиків (50 MO/мл пеніцилін, 50 мг/мл стрептоміцин). Функціональну активність визначали шляхом підрахунку кількості клітинних агрегатів після 14 діб культивування із подальшим вилученням індивідуальних колоній.

\section{Результати та їх обговорення}

Для постановки діагнозу та верифікації патологічного процесу у клініці проведено комплекс стандартних методів вивчення біологічного матеріалу у вигляді пунктатів кісткового мозку, забору венозної крові, мазків периферійної крові та кісткового мозку. У хворих на ХМЛ визначали лейкоцитоз зі зсувом до незрілих клітин гранулоцитарного ряду, у деяких пацієнтів - появу поодиноких бластних клітин у периферійній крові (рис. 1). Вміст лейкоцитів був значно підвищеним у зразках пацієнтів, які ще не отримували лікування (до $231,2 \times 10 \%$ ), іноді спостерігали «базофільно-еозинофільну асоціацію», кількість бластних клітин у периферійній крові коливалась у межах 0,3-6,5 × 10\% /л, у кістковому мозку - від 1,7 до 8,5 \%.

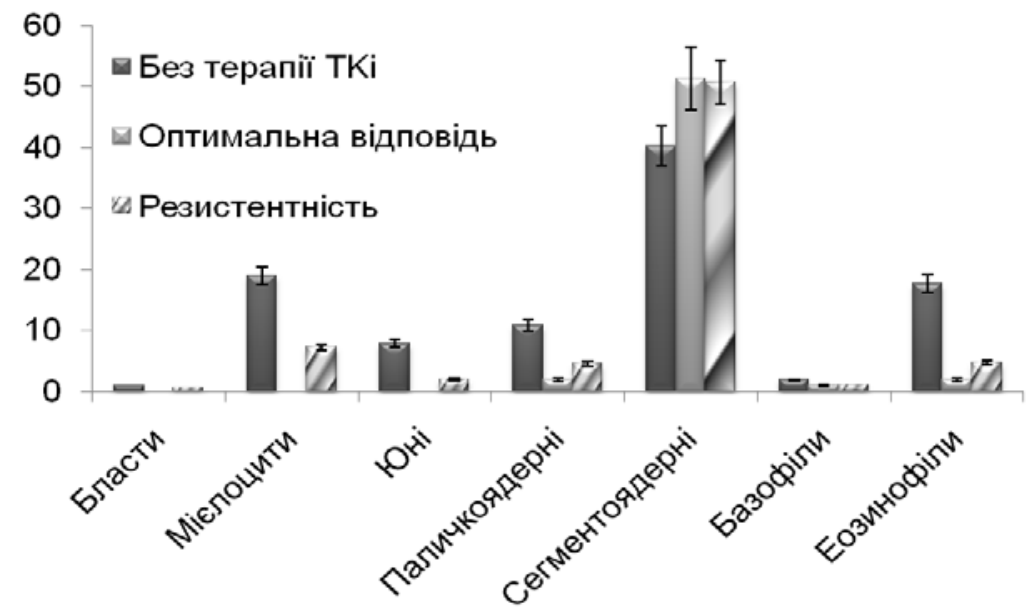

Рис. 1. Клітинний склад периферійної крові різних груп осіб із ХМЛ

Кількість еритроцитів у більшості випадків перебувала у межах норми та коливалась від 2,5 × 10 12 л до 4,7 × 102/л, вміст гемоглобіну - 72-145 г/л. У $60 \%$ паціснтів рівень тромбоцитів залишався в нормі (у пацієнтів із ранніми стадіями захворювання), проте у деяких випадках спостерігався тромбоцитоз до $755 \times 10^{9} /$ л.

Аналіз клітинного складу кісткового мозку також показав підвищення рівня незрілих клітин мієлоїдної лінії відносно більш зрілих форм для груп осіб з альтернативним лікуванням гідроксисечовиною та у випадку резистентності до лікування (рис. 2). Спостерігалось також достовірне підвищення кількості еозинофільних клітин у першій групі.

Із метою виявлення особливостей колоніє- та кластероутворення в культурі проводили кількісний облік і аналіз морфологічного складу клітинних агрегатів, які утворились в агарі в результаті 14-добового культивування клітин кісткового мозку хворих на ХМЛ у культурах in vitro. За колонію (колонієутворювальна одиниця гранулоцитарно-макрофагальна, КУО-ГМ) приймали скупчення понад 40 клітин (рис. 3). Клітинні агрегати 20-40 клітин вважали кластером (кластероутворювальна одиниця, КлУО). 


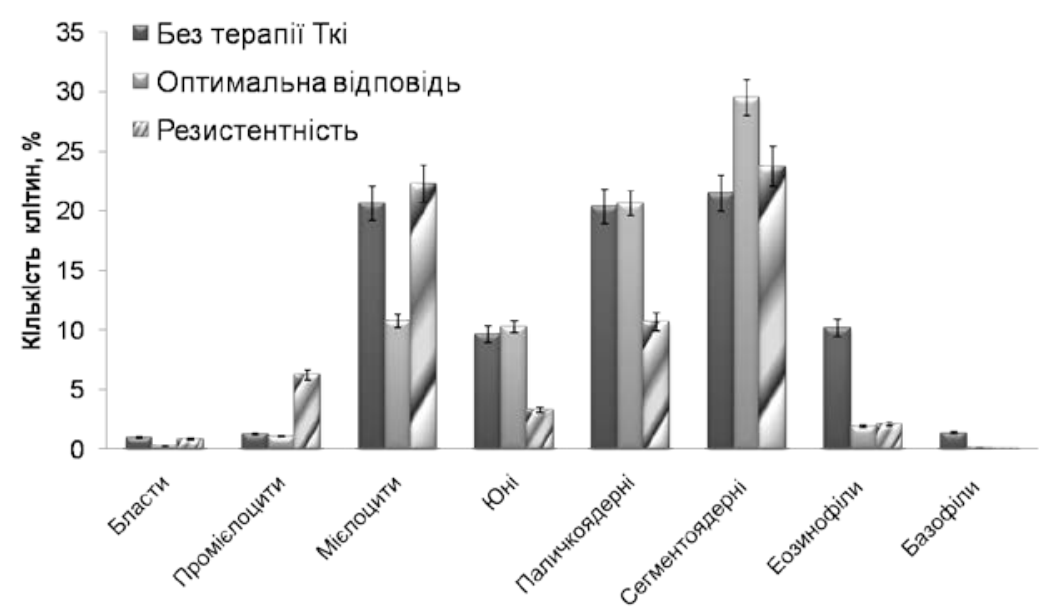

Рис. 2. Клітинний склад кісткового мозку різних груп осіб із ХМЛ

a
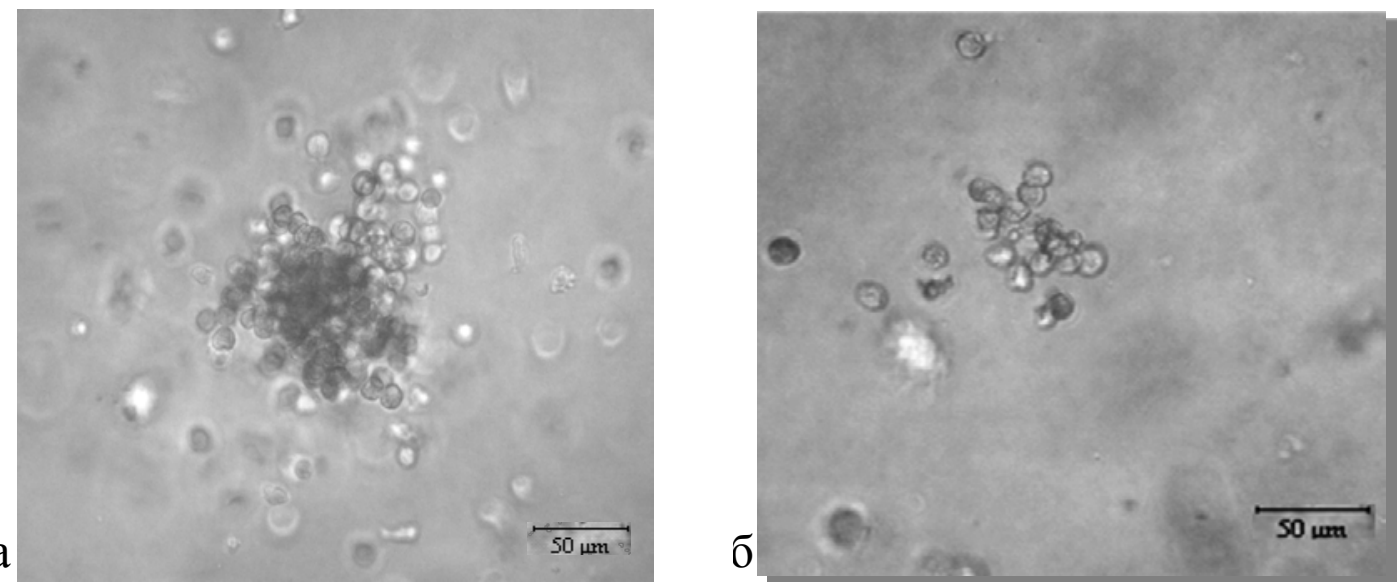

Рис. 3. Типи клітинних агрегатів кісткового мозку пацієнтів із ХМЛ на 14-ту добу культивування: $a$ - колонія, $\sigma$ - кластер

Отримані зразки поділено на дві групи за відповіддю пацієнта на терапію. Оптимальною відповіддю вважали досягнення повної гематологічної та цитогенетичної ремісії упродовж 12 місяців від початку лікування $(\mathrm{Ph}+=0 \%)$, резистентністю до терапії - коли досягалася гематологічна відповідь, однак цитогенетична відповідь була частковою або взагалі відсутньою $(\mathrm{Ph}+>0 \%)$. Ще одну групу складали зразки пацієнтів, які отримували альтернативне лікування (гідроксисечовина). Аналіз особливостей росту гемопоетичних клітин хворих на ХМЛ показав, що у групі пацієнтів на етапі встановлення діагнозу та без лікування ТКі спостерігалося інтенсивне утворення колоній - середнє значення складало 65,8 (варіювало у межах 3-140) на $1 \times 10^{5}$ мієлокаріоцитів (рис. 4), проте це значення достовірно не відрізнялось від значень КУО-ГМ для інших досліджених груп.

Функціональна активність клітин-попередників кісткового мозку осіб, які демонструють повну відповідь на терапію препаратом Іматиніб, була достовірно нижчою $(p<0,05)$ ефективності колонієутворення для зразків кісткового мозку осіб із відсутністю відповіді на терапію. Середня кількість КУО-ГМ для першої із зазначених 
груп склала 29,3 (0-68) на $1 \times 10^{5}$ мієлокаріоцитів проти 79,3 (2-188) на $1 \times 10^{5}$ мієлокаріоцитів КУО-ГМ для другої групи.

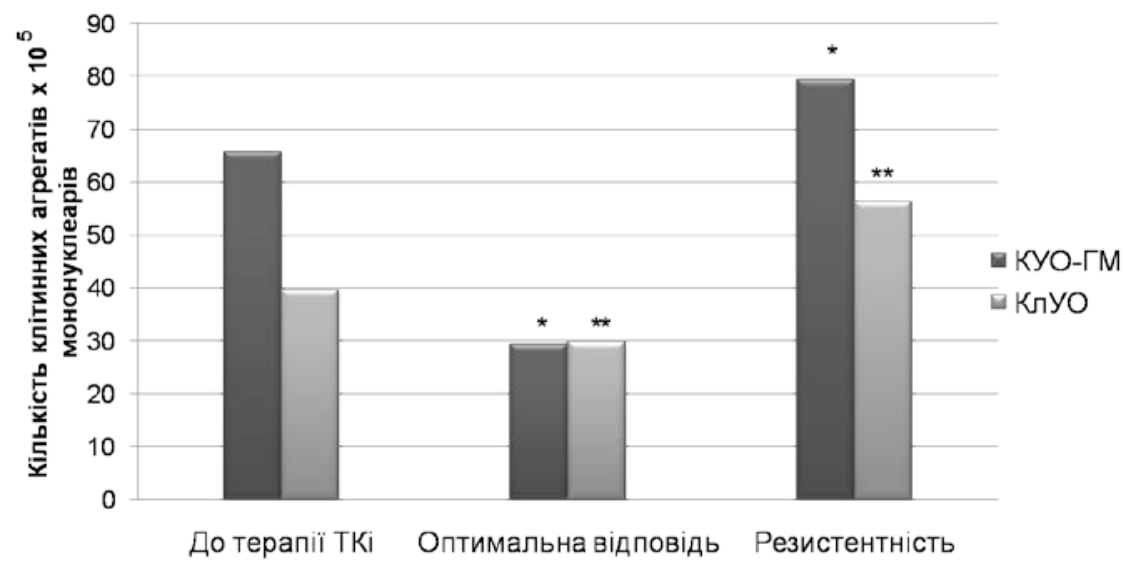

Рис. 4. Показники ефективності утворення колоній і кластерів для різних груп паціснтів
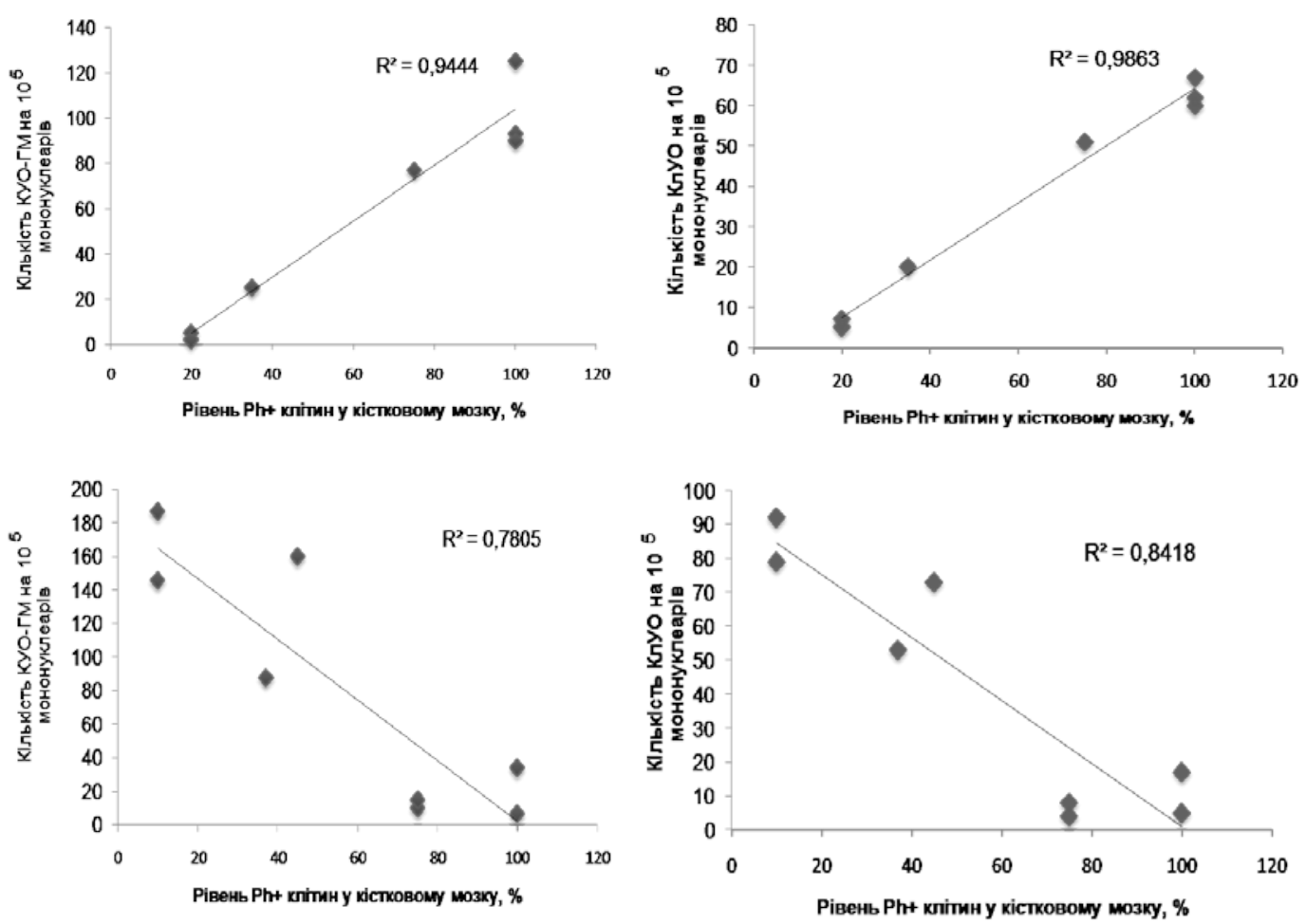

Рис. 5. Кореляція між рівнем функціональної активності клітин-попередників кісткового мозку та відсотком Ph+ клітин: $a$, $\sigma$ - для групи осіб з альтернативним лікуванням гідроксисечовиною (КУО-ГМ та КлУО, відповідно); в, г - для групи осіб із резистентністю до терапії ТКі (КУО-ГМ та КлУО, відповідно)

Подібна тенденція спостерігалась також і для середніх значень кластерів у трьох досліджуваних групах. Для зразків кісткового мозку осіб, що не отримували лікування ТКі, показник КлУО складав 39,6 (5-67) на $1 \times 10^{5}$ мієлокаріоцитів, що достовірно не відрізнялося від показників груп співставлення. Як показано на рисунку 3 , достовірну 
відмінність $(p<0,05)$ було виявлено при порівнянні ефективності утворення кластерів у групах із повною відповіддю (середнє значення 29,8 на $1 \times 10^{5}$ мієлокаріоцитів) та відсутністю відповіді на терапію (середнє значення 56,3 на $1 \times 10^{5}$ мієлокаріоцитів). Також виявлено кореляцію між показниками колонієутворення та відсотком $\mathrm{Ph}+$ клітин у кістковому мозку (рис. 5). Така кореляція була позитивною для групи осіб, які отримували альтернативне лікування гідроксисечовиною, що вказує на BCR/ABL-індуковане зростання проліферативної активності клітин-попередників кісткового мозку при ХМЛ.

Для групи осіб із резистентністю до терапії ТКі кореляція між кількістю клітинних агрегатів та відсотком $\mathrm{Ph}+$ клітин була негативною, що може бути наслідком накопичення $\mathrm{Ph}+$ клітин, які перебувають у стані спокою (фазі $\mathrm{G}_{0}$ клітинного циклу) та нечутливі як до дії екзогенних ростових факторів, так і до ТКі. Дослідження клітинного складу отриманих клітинних агрегатів дозволить краще зрозуміти особливості клітин-попередників при резистентності до ТКі.

\section{Висновки}

Результати досліджень вказують на наявність особливостей утворення клонів клітинами кісткового мозку осіб із ХМЛ, а також на прямий взаємозв'язок між функціональною активністю стовбурових клітин і клітин-попередників, та корелюють із рівнем цитогенетичної відповіді на терапію препаратами ТКі. Отримані дані підтверджують пригнічувальну дію інгібіторів тирозинкінази на гемопоетичну клітину та зниження проліферативної активності кісткового мозку у хворих із ХМЛ. Зміни функціональної активності клітин-попередників при ХМЛ відображають процеси лейкемічної трансформації, а описаний метод можна використовувати для моніторингу індивідуальної чутливості відповіді на терапію ТКі та розвитку бластної трансформації.

\section{Бібліографічні посилання}

1. Дягиль И. С. Субоптимальный ответ при лечении иматинибом ХМЛ как критерий риска развития резистентности // Укр. журнал гематології та трансфузіології. - 2009. - № 4 (9). - С. $27-29$.

2. Hughes T. Clinical strategies to achieve an early and successful response to tyrosine kinase inhibitor therapy / T. Hughes, A. Hochhaus // Semin Hematol. - 2009. - Vol. 46. - P. 111-115.

3. Human chronic myeloid leukemia stem cells are insensitive to imatinib despite inhibition of BCR-ABL activity / A. S. Corbin, A. Agarwal, M. Loriaux et al. // J. of Clin. Inv. - 2011. - Vol. 121. - N 1. P. 396-409.

4. Leber B. CML biology for the clinician in 2011: Six impossible things to believe before breakfast on the way to cure // Curr. Oncol. - 2011. - Vol. 18, N 4. - P. 185-190.

5. Philadelphia chromosome $\left(\mathrm{Ph}_{1}\right)$-negative chronic myelogenous leukemia (CML): A clonal disease with origin in a multipotent stem cell / P. J. Fialkow, R. J. Jacobson, J. W. Singer et al. // Blood. 1980. - Vol. 56, N 1. - P. 70-73.

6. Predictors of primary imatinib resistance in chronic myelogenous leukemia are distinct from those in secondary imatinib resistance / W. W. Zhang, J. E. Cortes, H. Yao et al. // J. Clin. Oncol. - 2009. Vol. 27, N 22. - P. 3642-3649. 